\title{
STUDIES ON THE ACTIVATION OF A SERUM ESTERASE WITH ETHER AND ITS RELATIONSHIP TO C'1-ESTERASE *
}

\author{
By VIRGINIA H. DONALDSON \\ (From the Research Division of the Cleveland Clinic Foundation and the Frank E. Bunts \\ Educational Institute; and the Department of Medicine, Western Reserve University \\ School of Medicine, Cleveland, Ohio)
}

(Submitted for publication August 22, 1960; accepted December 2, 1960)

The first component of complement probably exists as the precursor of an enzyme tentatively identified as an esterase (1-3). Under various circumstances, this proesterase may be activated by contact with antigen-antibody aggregates (1, 4 ), by plasma $(5,6)$, and when partially purified, by appropriate adjustment of physicochemical conditions $(2,6)$. The possibility that activation of this proesterase is related to complement fixation $(1,4,6,7)$, to immune hemolysis $(8)$, and to immune cytotoxicity (9) has received some experimental support. The present paper describes still another way in which esterase activity may be produced in preparations containing the first component of complement.

Although the proenzymatic nature of complement has been postulated for many years (10), indirect evidence supporting this view came only when the effect of plasmin upon complement was restudied $(1,4,5)$. Plasmin, a proteolytic enzyme of serum and plasma effective near neutrality, has an inhibitory effect upon complement. Pillemer, Ratnoff, Blum and Lepow (5) found that the first, second and fourth components of complement were inactivated by plasmin or streptokinase. However, the second and fourth components were inactivated only in preparations containing the first component (1). These and similar observations suggested that plasmin converted the first component of complement into an enzyme which inactivated the second and fourth components (1).

A second line of support for this concept has evolved from studies on the effect of incubating fresh serum with antigen-antibody aggregates at

* This work was supported by grants from the $\mathrm{Na}$ tional Heart Institute [HTS-5126 (c)], and the National Institute of Allergy and Infectious Diseases [E-1255 (C3)] of the National Institutes of Health, Bethesda, Md. low temperatures. Serum treated in this way loses some of the activity attributable to the first component of complement. Material may then be eluted from the antigen-antibody aggregate which hydrolyzes $\mathrm{N}$-acetyl-L-tyrosine ethyl ester and inactivates the fourth and second components of complement (7). The eluate does not contain hemolytic activity attributable to the first component of complement. On the other hand, a similar eluate obtained from antigen-antibody aggregates which have been inculbated with serum lacking the first component of complement has neither esterase activity nor the capacity to inactivate the fourth and second components. These observations are compatible with the view that the esterase activity present in the eluate is derived from the first component of complement.

Other evidence identifying the first component of complement with a proesterase has come from studies of a partially purified preparation of this component (2). At low $\mathrm{pH}$ and high ionic strength, such a preparation has hemolytic activity. Upon adjusting these modalities to physiological levels, the preparation loses its hemolytic activity, and concurrently acquires the ability to inactivate the fourth and second components of complement, and to hydrolyze $\mathrm{N}$-acetyl-L-tyrosine ethyl ester, $p$-toluene sulfonyl-L-arginine methyl ester, and certain other synthetic substrates. The susceptibility of $\mathrm{N}$-acetyl-L-tyrosine ethyl ester to hydrolysis by this preparation differentiates the active esterase from plasmin, which does not attack this substrate.

Using a different type of approach, Becker demonstrated that diisopropylfluorophosphate, which inhibits many types of esterases, can prevent the hemolytic activity of complement, apparently by specific inhibition of the first component (11). He has also shown that sensitized red cells, which have been treated with the first, second and fourth 
components of complement, hydrolyze $p$-toluene sulfonyl-L-arginine methyl ester (3).

All these observations have led to the hypothesis that the first component of complement is the precursor of an esterase which can interact with the fourth and second components of complement.

The data to be presented further identify the first component of complement with the precursor of a specific esterase. When fresh serum is extracted with ether in the manner to be described, the first, second and fourth components of complement are lost. At the same time, an esterase appears which can inactivate the fourth component of complement and hydrolyze N-acetyl-L-tyrosine ethyl ester. This enzyme can not be distinguished from an esterase derived from a partially purified preparation of the first component of complement ; it does not appear following ether extraction of serum from which the first component has been removed. The extraction of serum with ether may thus provide another means of converting the first component of complement to an esterase. This extraction also inactivates the human serum inhibitor of an esterase derived from partially purified first component of complement. A possible mechanism relating esterase activation to loss of this inhibitor will be discussed.

\section{NOMENCLATURE AND MATERIALS}

Complement is designated as $\mathrm{C}^{\prime}$, and the four known components as $\mathrm{C}^{\prime} 1, \mathrm{C}^{\prime} 2, \mathrm{C}^{\prime} 3$ and $\mathrm{C}^{\prime} 4$ in accordance with previous usage (12). The esterase prepared from a partially purified preparation of $\mathrm{C}^{\prime} 1$ by adjustment of $\mathrm{pH}$ and ionic strength (2) will be designated $C^{\prime} 1$-esterase, and that prepared by extracting serum with ether in the manner to be described, as ether-esterase. One unit of esterase activity, as defined by Levy and Lepow (13), is that amount of enzyme which will hydrolyze an amount of $\mathrm{N}$-acetyl-L-tyrosine ethyl ester equivalent to $0.5 \mu$ mole of titratable acid after incubation for $15 \mathrm{~min}$ utes under standardized conditions of assay. Serum reagents used to assay the components of complement and deficient, respectively, in $\mathrm{C}^{\prime} 1, \mathrm{C}^{\prime} 2, \mathrm{C}^{\prime} 3$ and $\mathrm{C}^{\prime} 4$ are designated as R1, R2, R3, and R4 (14). Their preparation has been described elsewhere $(1,4,14,15)$. Serum which had been heated for 30 minutes at $56^{\circ} \mathrm{C}$ was used in place of $\mathrm{R} 1$ in some assays measuring $\mathrm{C}^{\prime} 4$ inactivation.

Ether-esterase was tested for several other activities. In determining its plasmin inhibitor content, commercial human plasmin (Merck Sharp and Dohme, West Point, $\mathrm{Pa}$., lot no. 1108-86-M) was used. It was dissolved in buffer in concentrations of 400,40 and 4 fibrinolytic units (16) per $\mathrm{ml}$ of solution. To measure the plasminogen-actizator content of ether-esterase, the euglobulin fraction of normal citrated human plasma was prepared (17) and redissolved in buffer.

Streptokinase (High Purity, Lederle Laboratories, Pearl River, N. Y.) was dissolved in buffer in a concentration of 300 Christensen units per $\mathrm{ml}$ (18) for use in assays of the plasminogen content of ether-esterase. Lyophilized bovine fibrinogen (Warner Chilcott, Morris Plains, N. J.) was dissolved in water to contain $300 \mathrm{mg}$ of coagulable protein and $0.85 \mathrm{~g}$ of sodium chloride per $100 \mathrm{ml}$ of solution. Bovine thrombin (Topical Thrombin, Parke Davis Co., Detroit, Mich.) was dissolved in buffer in a concentration of 10 National Institutes of Health units per ml. Barbital-saline buffer was used in assays measuring components of the plasmin system.

Human serum was prepared from the blood of apparently healthy adults. The blood was allowed to clot in glass containers at room temperature for 1 to 2 hours, and then kept at $4^{\circ} \mathrm{C}$ for 8 to 12 hours. The serum was then separated by centrifugation at $2,500 \mathrm{rpm}$ at room temperature for 15 minutes, and stored at $-25^{\circ} \mathrm{C}$ for as long as 2 months before use.

Partially purified preparations of human serum inhibitor of C'1-esterase, a heat-labile $\alpha_{2}$-globulin $(13,19)$, were made available in the course of these studies. One preparation, representing a 100 - to 200 -fold purification of the inhibitor with respect to serum, was obtained by ammonium sulfate fractionation and column chromatography of human serum (20). This material was used in experiments showing its inhibitory effect on the hydrolysis of $\mathrm{N}$-acetyl-L-tyrosine ethyl ester, and the inactivation of $\mathrm{C}^{\prime} 4$ by ether esterase. A preparation representing a 500 -fold purification of the inhibitor with respect to serum (21) was subjected to ether extraction by the method described.

Citrated plasma was prepared by methods previously described (22) from the blood of normal individuals, and from that of patients with congenital deficiencies of various clotting factors.

Sensitized sheep erythrocytes for use in measuring the components of complement in a hemolytic system were prepared by published procedures (1).

Pneumococcal soluble specific capsular polysaccharide (type III) and its homologous rabbit antibody were used in the preparation of antigen-antibody aggregates. The aggregates were prepared from $200 \mu \mathrm{g}$ of antibody nitrogen, and $8 \mu \mathrm{g}$ of antigen per $\mathrm{ml}$ of solution. Each 1.0 $\mathrm{ml}$ aliquot of suspended aggregate was washed twice in $2.0 \mathrm{ml}$ of cold $0.15 \mathrm{M}$ sodium chloride prior to use.

Crystalline soybean trypsin inhibitor (Nutritional Biochemicals Corp., Cleveland, Ohio) was dissolved in a concentration of $5 \mathrm{mg}$ per $\mathrm{ml}$ of $0.15 \mathrm{M}$ sodium chloride.

Epsilon-aminocaproic acid (H. M. Chemical Co., Santa Monica, Calif.) was dissolved in water in a $0.2 \mathrm{M}$ solution.

Asbestos-filtered beef plasma was prepared as suggested by Owren and Aas (23). Barium sulfate-adsorbed oxalated beef plasma (Prothrombin Free Beef Plasma, Hyland Laboratories, Los Angeles, Calif.) was obtained 
commercially, and human-oxulated serum was prepared as recommended by Alexander (24).

Tissue thromboplastin for use in several assays for clotting factor activities was prepared by suspending $37.5 \mathrm{mg}$ of a commercial rabbit brain preparation (Difco, Detroit, Mich.) in $1.0 \mathrm{ml}$ of $0.15 \mathrm{M}$ sodium chloride. Casein was prepared as described by Norman (25). I)cnatured hemoglobin (Bovine Crystalline Hemoglobin, Armour Laboratories, Kankakee, Ill.) was prepared in a 2.2 per cent solution in urea (26).

Synthetic amino acid esters and dipeptides were obtained from commercial sources, or synthesized in the Department of Chemistry, Western Reserve University. They were dissolved in $0.2 \mathrm{M}$ solutions in $0.15 \mathrm{M}$ sodium chloride or in 2-methoxy ethanol (methyl Cellosolve, Matheson Co., Inc., Norwood, Ohio) as designated in Table $\mathrm{V}$.

Diethyl-ether (Mallinckrodt, St. Louis, Mo.) was used in the extraction procedure. Pyrex glassware which had been cleaned with a detergent (Dural $\mathrm{H}$, Wyandotte Chemicals, Wyandotte, Mich.), rinsed with tap water, and finally with distilled water, was used unless otherwise noted. Acidometric titrations were performed with a $1.0 \mathrm{ml}$ microsyringe (Micrometric Instrument Corp., Cleveland, Ohio).

Barbital-C $a^{++}-M y^{++}$buffer (16) for use in hemolytic complement assays, contained $1.5 \times 10^{-4} \mathrm{M} \mathrm{Ca}^{++}$and $5 \times$ $10^{-4} \mathrm{M} \mathrm{Mg}^{++}$, and had a $\mathrm{pH}$ of 7.4 at ionic strength 0.15 . Sodium phosphate buffer having a $\mathrm{pH}$ of 7.4 and ionic strength of 0.15 , was prepared by mixing one part of $\mathrm{M} / 15$ monobasic sodium phosphate with 4.2 parts of M/15 dibasic sodium phosphate (27). Barbital-saline buffer, having a $\mathrm{pH}$ of 7.4 and ionic strength of 0.15 , consisted of $7.3 \mathrm{~g}$ of sodium chloride, $2.76 \mathrm{~g}$ of barbital, and $2.06 \mathrm{~g}$ of sodium barbital diluted to a volume of $1 \mathrm{~L}$ with distilled water.

\section{METHODS}

1. Esterolytic assays. The esterase activity resulting from ether extraction of serum was measured using the variety of synthetic substrates listed in Table V. The change in titratable acidity after incubating the enzyme with the substrate at $37^{\circ} \mathrm{C}$ for variable intervals was determined. A micro-formol titration of these mixtures was performed as has been described $(19,28)$.

A standardized assay of the hydrolysis of N-acetyl-Ltyrosine ethyl ester was used for measuring units of C'1-esterase or ether-esterase activity (13). This technique involves the titration of the acid liberated during incubation for 15 minutes at $37^{\circ} \mathrm{C}$ of the following mixture : $1.88 \mathrm{ml}$ of sodium phosphate buffer, $0.5 \mathrm{ml}$ of enzyme, and $0.125 \mathrm{ml}$ of $1.6 \mathrm{M} \mathrm{N}$-acetyl-L-tyrosine ethyl ester.

The hydrolysis of the other synthetic amino acid esters by ether-esterase was measured in a similar fashion, but the mixtures were incubated for 24 hours before titration. Ten $\pm 1 \mathrm{U}$ of esterase activity was included in each incubation mixture. The final concentration of each substrate in these mixtures was $0.02 \mathrm{M}$ in a total volume of $4.0 \mathrm{ml}$. Hydrolysis of L-lysine ethyl ester by $\mathrm{C}^{\prime} 1$-estcrase and ether-esterase was measured by means of a minor modification of the Hestrin method $(29,30)$ after incubation for 24 hours.

2. Human serum inhibitor of C'1-esterase. Inhibition of $\mathrm{C}^{\prime} 1$-esterase was measured by a method published earlier (13). A standardized amount of $C^{\prime} 1$-esterase having $40 \pm 2 \mathrm{C}$ of activity per $\mathrm{ml}$ of solution was used as enzyme. Inhibition was determined by observing the decrease in hydrolysis of $\mathrm{N}$-acetyl-L-tyrosine ethyl ester caused by various volumes of test sample.

3. Detcrmination of componcuts of complement. The amounts of $\mathrm{C}^{\prime} 1, \mathrm{C}^{\prime} 2, \mathrm{C}^{\prime} 3$ and $\mathrm{C}^{\prime} 4$ in the materials tested were titrated, by published methods $(1,14,15)$, in systems markedly deficient in the component being measured. The reagents deficient in each of the four components fulfilled the requirements described elsewhere for $\mathrm{R} 1, \mathrm{R} 2, \mathrm{R} 3$ and $\mathrm{R} 4(14,15)$. A 50 per cent hemolytic endpoint was estimated.

4. Protein substrates. The digestion of casein by etheresterase was measured following the incubation of a mixture of $1.3 \mathrm{ml}$ of this enzyme in sodium phosphate buffer with $5.7 \mathrm{ml}$ of 5 per cent casein at $37^{\circ} \mathrm{C}$ for 1 and 3 hours. Hydrolysis of casein by ether-esterase preparations extracted with and without soybean trypsin inhibitor was measured. The extent of digestion of denatured hemoglobin which occurred during the incubation of $3.0 \mathrm{ml}$ of ether-esterase in sodium phosphate buffer with $2.0 \mathrm{ml}$ of denatured hemoglobin at $37^{\circ} \mathrm{C}$ was determined after 1 and 24 hours. In each instance, the tyrosyl-nitrogen soluble in $0.3 \mathrm{~N}$ trichloroacetic acid which had been liberated during incubation was measured by a modification of the method of Folin and Ciocalteu (31).

5. Other properties of ether-csterase. Several clotting factors were measured by methods described elsewhere $(22,32)$. In essence, the presence of each clotting activity was measured by observing the effect of etheresterase upon the recalcified clotting time of plasmas believed to be markedly deficient in the factor to be tested. Factors primarily effective in accelerating the conversion of prothrombin were measured by determining the effect of ether-esterase on the one-stage prothrombin time (33) of a plasma deficient in the factor to be measured. The presence of thrombin in ether-esterase was evident if 0.2 $\mathrm{ml}$ of this material converted an equal volume of fibrinogen to fibrin at $37^{\circ} \mathrm{C}$.

Ether-esterase was tested for components of the plasmin system. Plasmin, plasminogen and plasmin inhibitors were tested by minor modifications of methods published earlier (5). An activator of plasminogen was measured by noting the time required for complete lysis of a clot composed of $0.3 \mathrm{ml}$ of plasma euglobulins, $0.1 \mathrm{ml}$ of ether-esterase, and $0.1 \mathrm{ml}$ of thrombin.

Barbital-saline buffer was substituted for ether-esterase in the control mixtures in each of these assay systems. In each instance, the time required for complete lysis of a clot was measured from the point at which thrombin was added to a mixture. The assays for clotting factor 
activities and for components of the plasmin system were performed in duplicate in Pyrex tubes having an internal diameter of $8 \mathrm{~mm}$. Clot lysis times were measured at $37^{\circ} \mathrm{C}$ in stoppered tubes. Recalcified clotting times were performed at $25^{\circ} \mathrm{C}$ and prothrombin times at $37^{\circ} \mathrm{C}$.

The tyrosyl-nitrogen content of various preparations of ether-esterase was ascertained by using a minor modification of the method of Folin and Ciocalteu (31).

\section{EXPERIMENTAL}

1. Generation of $N$-acetyl-I-tyrosine ethyl esterase activity by extraction of serum with ether. MacFarlane's procedure for the extraction of lipids from serum was varied slightly in the present experiments (34). This method is said to remove 70 per cent of the total serum lipids in one extraction (34).

Normal human serum plus 0.3 its volume of ether was shaken in a separatory flask, and this mixture was immediately placed in a $-30^{\circ} \mathrm{C}$ deep-freeze for sufficient time to lower its temperature to $-25^{\circ} \mathrm{C}$. The mixture was then thawed in an ice bath at a temperature of $2^{\circ}$ to $4^{\circ} \mathrm{C}$ for several hours. When the material was thawed, three distinct phases were visible: at the top, a clear yellow ether layer; below this, a dense cloudy precipitate; and at the bottom, a serum layer which was usually clear. The topmost layer and the middle layer containing precipitate were removed as one and centrifuged together in clean aluminum cups at $16,000 \times \mathrm{G}$ for 30 to 40 minutes at $4^{\circ} \mathrm{C}$ in an International PR-I refrigerated centrifuge. The supernatant fluid was carefully decanted. The precipitate, to be referred to as etheresterase, was suspended in $0.15 \mathrm{M}$ sodium chloride. All three fractions were tested for units of esterase activity using the standardized assay described in the previous section. These fractions were stored at $-25^{\circ} \mathrm{C}$.

The three fractions which were separated by this procedure differed in their ability to hydrolyze $\mathrm{N}$-acetyl-L-tyrosine ethyl ester. The extracted serum contained little of this esterolytic activity. It had no spontaneous fibrinolytic activity as if it contained no active plasmin. The clear ether supernatant layer had no esterolytic activity. The precipitated material, however, contained large though variable amounts of esterolytic activity (from 5 to $11.5 \mathrm{U}$ per $\mathrm{ml}$ of the original serum extracted; mean $=7.9 \mathrm{U}$ per $\mathrm{ml}$ ) but no fibrinolytic activity. This material was only partially soluble in saline and in the buffers described. When the suspension of ether-esterase was centrifuged once at $16,000 \times \mathrm{G}$, the activity was about evenly distributed between the cloudy supernatant fluid and the precipitated material. When this supernatant fluid was recentrifuged in the same manner, and the precipitate separated and combined with the original, the combined precipitates contained about two-thirds of the total activity extracted from the serum.

The quantity of ether-esterase per milligram of nitrogen differed from one preparation to another. Variable success was had in sharply separating the bottom serum layer from the intermediate layer which contained most of the activity. The tyrosyl-nitrogen content of several preparations of ether-esterase varied from 0.13 to 0.5 per cent of that of the original serum (mean value $=0.4$ per cent ). Many preparations were tested for the amount of activity as related to protein content. Values ranged from 111 to $309 \mathrm{U}$ of ether-esterase per $\mathrm{mg}$ of tyrosyl-nitrogen. The specific activity of ether-esterase exceeded that of C'1-esterase preparations described earlier (2) which contained about $100 \mathrm{U}$ or less of activity per mg of tyrosyl-nitrogen.

When serum was extracted with the same relative volume of ether at $4^{\circ} \mathrm{C}$ without freezing and thawing, almost no precipitable esterase activity could be found. However, about $6 \mathrm{U}$ of activity was found in each milliliter of the extracted serum.

The effect of temperature of thawing upon the development of ether-esterase was tested. Large amounts of $\mathrm{N}$-acetyl-L-tyrosine ethyl esterase activity were found in the precipitated material from samples thawed at $4^{\circ}$ and $25^{\circ} \mathrm{C}$. I.ess than half as much was found in this fraction of a comparable sample after thawing at $37^{\circ} \mathrm{C}$. The cloudy intermediate layer which formed upon thawing at colder temperatures was barely visible after thawing at $37^{\circ} \mathrm{C}$.

2. Requirement for $C^{\prime} 1$ for activation of etheresterase. A $10 \mathrm{ml}$ sample of serum which had been heated to $56^{\circ} \mathrm{C}$ for 30 minutes was extracted in the manner described. Such serum contains no $\mathrm{C}^{\prime} 1$ or $\mathrm{C}^{\prime} 2$. In addition, 5-ml samples of $\mathrm{R} 1$ and $\mathrm{R} 2$ preparations were similarly extracted with $1.5 \mathrm{ml}$ of ether. The resulting fractions of these preparations were then tested for ether-esterase 
activity in order to determine whether or not $C^{\prime} 1$ was required for its development.

When R1 or serum which had been heated to $56^{\circ} \mathrm{C}$ for 30 minutes was extracted, no $\mathrm{N}$-acetyl-Ltyrosine ethyl esterase activity was found in any of the fractions. However, when the fractions resulting from the extraction of R2 were tested, ether-esterase activity was found both in the resuspended precipitate and in the supernatant fluid separated from the active precipitate, as was the case with fresh serum. These observations demonstrate that the removal of $C^{\prime} 1$ from the original serum prevents the appearance of ether-esterase.

3. Role of plasmin in ether-esterase activation. One possible explanation for the effect of ether on activation of a serum esterase was that ether removed the plasmin inhibitor in serum (35) and plasmin was then activated. This in turn converted the first component of complement to its esterase form $(1,4,5)$. To test this possibility, serum was treated with ether in the presence of soybean trypsin inhibitor, an inhibitor of plasmin, and of epsilon-aminocaproic acid, an inhibitor of the activation of plasminogen (36).

Before it was shaken with ether, $1.0 \mathrm{ml}$ of a solution containing $5 \mathrm{mg}$ of soybean inhibitor or $1.0 \mathrm{ml}$ of a $0.2 \mathrm{M}$ epsilon-aminocaproic acid solution was mixed with each of two $10-\mathrm{ml}$ samples of serum. One $\mathrm{ml}$ of sodium phosphate buffer was added to a third $10-\mathrm{ml}$ sample of serum, serving as a control mixture. Esterase activity in the fractions resulting from the ether extraction of each mixture was compared.

When either of these inhibitors was mixed with serum prior to extraction, no interference with

TABLE I

Inactivation of $C^{\prime} 4$ by ether-esterase *

\begin{tabular}{cc}
\hline $\begin{array}{c}\text { Ether-esterase in } \\
\text { incubation mixture }\end{array}$ & Residual C'4 in R1 \\
\hline$U$ & $U / m l$ \\
0 & $\geqslant 360$ \\
0.12 & 240 \\
0.24 & 120 \\
0.48 & 60 \\
0.95 & 40 \\
1.9 & 20
\end{tabular}

* In this experiment $0.1 \mathrm{ml}$ of dilutions of ether-esterase was incubated with $0.15 \mathrm{ml}$ of $0.15 \mathrm{M}$ sodium chloride at $37^{\circ} \mathrm{C}$ for 10 minutes. Then, $0.75 \mathrm{ml}$ of $\mathrm{R} 1$ was added to each tube and the mixtures were incubated at $37^{\circ} \mathrm{C}$ for 30 minutes. The final mixtures were tested for residual $\mathrm{C}^{\prime} 4$ in a hemolytic system.
TABLE II

Effect of purified human serum inhibitor of $C^{\prime} 1$-esterase on inactivation of $C^{\prime} 4$ by ether-esterase *

\begin{tabular}{cccc}
\hline \hline $\begin{array}{c}\text { Esterase } \\
\text { in incu- } \\
\text { bation } \\
\text { mixture }\end{array}$ & $\begin{array}{c}\text { Esterase- } \\
\text { inhibitor }\end{array}$ & $\begin{array}{c}\text { Esteraset } \\
\text { (esterase- } \\
\text { inhibitor) }\end{array}$ & $\begin{array}{c}\text { Residual } \\
\mathrm{C}^{\prime} 4 \text { in R1, }\end{array}$ \\
\hline$U$ & $U$ & Net $U$ & $U / \mathrm{ml}$ \\
1.0 & 0 & 1.0 & 30 \\
1.0 & 0.015 & 0.85 & 40 \\
1.0 & 0.030 & 0.70 & 60 \\
1.0 & 0.060 & 0.40 & 80 \\
1.0 & 0.075 & 0.25 & 120 \\
1.0 & 0.10 & 0 & $\geqslant 240$ \\
1.0 & 0.20 & 0 & $\geqslant 360$ \\
0 & 0 & 0 & $\geqslant 360$ \\
\hline
\end{tabular}

* In this experiment, $0.1 \mathrm{ml}$ of ether-esterase was incubated with $0.15 \mathrm{ml}$ of the inhibitor or with $0.15 \mathrm{M}$ sodium chloride at $37^{\circ} \mathrm{C}$ for 10 minutes. Then, $0.75 \mathrm{ml}$ of $\mathrm{R} 1$ was added and this mixture was incubated at $37^{\circ} \mathrm{C}$ for $30 \mathrm{~min}$ utes. The $C^{\prime} 4$ remaining in the mixture was then measured.

+ Calculations assume that $0.1 \mathrm{U}$ of inhibitor inhibits 1.0 $\mathrm{U}$ of esterase activity (13).

the generation of ether-esterase activity could be demonstrated. Soybean inhibitor extracted in this manner could still inhibit plasmin. Etheresterase could be produced even in the presence of a plasmin inhibitor and of an inhibitor of plasminogen activation; plasmin activation was not required for production of ether-esterase.

4. Effect of ether extraction on the serum inhibitor of C'1-esterase. An inhibitor of C'1-esterase has been demonstrated in normal human serum $(13,19)$. This inhibitor interferes with the capacity of $C^{\prime} 1$-esterase to inactivate $C^{\prime} 4$ (20), and with its ability to hydrolyze $\mathrm{N}$-acetyl-L-tyrosine ethyl ester (13). Serum extracted with ether by the method described was tested for its ability to prevent the hydrolysis of this substrate by $\mathrm{C}^{\prime} 1$-esterase. No inhibitory activity was detected in this serum, even though it had contained a normal amount of inhibitor (about $5 \mathrm{U}$ per $\mathrm{ml}$ ) prior to extraction. A search for inhibitory activity in the other fractions from this extraction was unrewarding; recombining these fractions did not restore inhibitory activity.

When purified human serum inhibitor was extracted with ether, its titer decreased from $6 \mathrm{U}$ to less than $1 \mathrm{U}$ per $\mathrm{ml}$. The serum inhibitor of $\mathrm{C}^{\prime} 1$ esterase, then, was largely or completely destroyed in the process of extraction with ether.

5. Relation of ether-esterase to complement. a) Ether esterase preparations were incubated with 
$\mathrm{R} 1$ and the mixtures then tested for $\mathrm{C}^{\prime} 4$. In these experiments, the degree of inactivation of $\mathrm{C}^{\prime} 4$ was enhanced with increasing concentration of etheresterase (Table I). This effect of ether-esterase on $C^{\prime} 4$ is comparable to that of $C^{\prime} 1$-esterase (2).

b) The ability of the purified human serum inhibitor to C'1-esterase to interfere with the inactivation by ether-esterase of $C^{\prime} 4$ in $R 1$ and with the hydrolysis of $\mathrm{N}$-acetyl-L-tyrosine ethyl ester was tested. The inactivation of $\mathrm{C}^{\prime} 4$ by etheresterase was inhibited in a stoichiometric fashion (Table II). Similarly, the esterolytic activity of ether-esterase decreased progressively in the presence of increasing amounts of this inhibitor (Table III). At lower concentrations of ether-

TABLE III

Effect of purified human serum inhibitor of $C^{\prime} 1$-esterase on esterolytic activity of ether-esterase *

\begin{tabular}{cccc}
\hline Esterase & Inhibitor & $\begin{array}{c}\text { Observed } \\
\text { inhibition }\end{array}$ & $\begin{array}{c}\text { Predicted } \\
\text { inhibition }\end{array}$ \\
\hline$U / m l$ & $U / m l$ & $U / m l$ & $U / m l \dagger$ \\
33 & 0 & 0 & 0 \\
33 & 1.0 & 12 & 10 \\
33 & 1.5 & 20 & 15 \\
33 & 2.0 & 29 & 20 \\
33 & 2.5 & 29 & 25 \\
33 & 3.0 & 32 & 30
\end{tabular}

* In this experiment, a standardized assay for $\mathrm{C}^{\prime} 1$ esterase inhibition was used (13). The hydrolysis of $\mathrm{N}$-acetyl-L-tyrosine ethyl ester in a final concentration of $0.08 \mathrm{M}$ by a mixture of a constant amount of esterase and variable amounts of inhibitor was measured.

+ Calculations assume that $0.1 \mathrm{U}$ of inhibitor inhibits $1.0 \mathrm{U}$ of esterase, as previously shown with $\mathrm{C}^{\prime} 1$-esterase (13).

esterase, such as those which occur in the presence of greater concentrations of inhibitor, the titration of ester hydrolysis is less accurate than the titration of residual $C^{\prime} 4$. In the esterolytic assay, therefore, the apparent discrepancies from stoichiometry between inhibitor concentration and residual ether-esterase activity were within experimental error.

In other experiments, fresh normal human serum was found to inhibit ether-esterase and $\mathrm{C}^{\prime} 1$ esterase to a nearly identical degree. Both of these enzymes, then, were inhibited by the same fraction of human serum, and both were inhibited to the same degree by whole serum $(19,37)$.

c) The relative amounts of each of the components of complement in the original serum, the extracted serum, and the ether-esterase prepared
TABLE IV

Uptake of esterase activity by antigen-antibody aggregates *

\begin{tabular}{lcc}
\hline Esterase & $\begin{array}{c}\text { Actual units } \\
\text { of esterase } \\
\text { incubated } \\
\text { with ag- } \\
\text { gregate }\end{array}$ & $\begin{array}{c}\text { Units of } \\
\text { esterase } \\
\text { recovered } \\
\text { with ag- } \\
\text { gregate }\end{array}$ \\
\hline C' $^{\prime} 1$ & 22 & 6.0 \\
C'1 $^{\prime}$ & 13.3 & 4.2 \\
Ether & 15.6 & 8.6 \\
Ether & 7.4 & 4.0
\end{tabular}

* In this experiment, washed antigen-antibody aggregates and $10^{-3} \mathrm{M} \mathrm{Ca}^{++}$were incubated with $1.0 \mathrm{ml}$ of each esterase, containing the amount of activity listed, at $0^{\circ} \mathrm{C}$ for 30 minutes. The aggregates were then separated by centrifugation in the cold, washed, resuspended in $0.5 \mathrm{ml}$ of $0.15 \mathrm{M} \mathrm{NaCl}$, and tested for $\mathrm{N}$-acetyl-L-tyrosine ethyl esterase activity in a standardized system (13).

therefrom were determined. None of the four components, as measured in a hemolytic system, was present in ether-esterase. In the extracted serum, $C^{\prime} 1, C^{\prime} 2$ and $C^{\prime} 4$ were completely removed, but the amount of $\mathrm{C}^{\prime} 3$ remained unchanged.

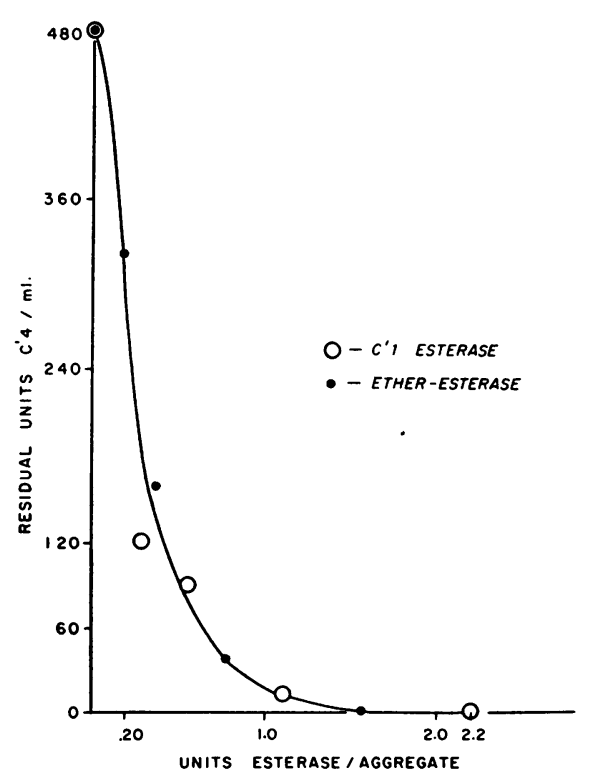

Fig. 1. C'4 inactivation Resulting from transfer OF C'1 ESTERASE AND ETHER-ESTERASE TO PREFORMED ANTIGEN-ANTIBODY AGGREGATES. In this experiment, washed antigen-antibody aggregates were incubated with $1.0 \mathrm{ml}$ of each esterase, in the concentrations plotted, and $10^{-3} \mathrm{M}$ $\mathrm{Ca}^{++}$at $0^{\circ} \mathrm{C}$ for 30 minutes. These aggregates were then reacted with heated serum $\left(56^{\circ}\right.$ for 30 minutes) at $0^{\circ} \mathrm{C}$ for 30 minutes. The precipitates were separated by centrifugation in the cold and the supernatant fluids titrated for $\mathrm{C}^{\prime} 4$ activity. 
d) The uptake of ether-esterase and C'1-esterase by antigen-antibody aggregates was compared. Washed aggregates were incubated with $1.0 \mathrm{ml}$ of various concentrations of each esterase preparation in the presence of $10^{-3} \mathrm{M} \mathrm{Ca}^{++}$at $0^{\circ} \mathrm{C}$ for 30 minutes. The aggregates were then centrifuged at $3,000 \mathrm{rpm}$ for 20 minutes at $0^{\circ} \mathrm{C}$, separated from the supernatant fluids, and washed with $2.0 \mathrm{ml}$ of $0.04 \mathrm{M}$ sodium chloride. Each aggregate, suspended in $0.5 \mathrm{ml}$ of $0.15 \mathrm{M}$ sodium chloride, was tested for its ability to hydrolyze $\mathrm{N}$-acetyl-L-tyrosine ethyl ester in the standardized assay system. The supernatant fluids were similarly tested.
Other esterase-treated aggregates were tested for their ability to inactivate $\mathrm{C}^{\prime} 4$ in serum which had been heated for 30 minutes at $56^{\circ} \mathrm{C}$. The aggregates and heated serum were incubated for 30 minutes at $0^{\circ} \mathrm{C}$, and then centrifuged in the cold for 20 minutes at $3,000 \mathrm{rpm}$. The supernatant fluids were tested for residual $\mathrm{C}^{\prime} 4$ activity.

A significant amount of $\mathrm{N}$-acetyl-L-tyrosine ethyl esterase activity was found on antigen-antibody aggregates which had been incubated either with $\mathrm{C}^{\prime} 1$ or ether-esterase (Table IV). Ester hydrolysis was measured at low concentrations of esterase. Under these circumstances the method is less accurate, as has been pointed out, perhaps

TABLE $V$

Some synthetic substrates of $C^{\prime} 1$-esterase (19) and ether-esterase*

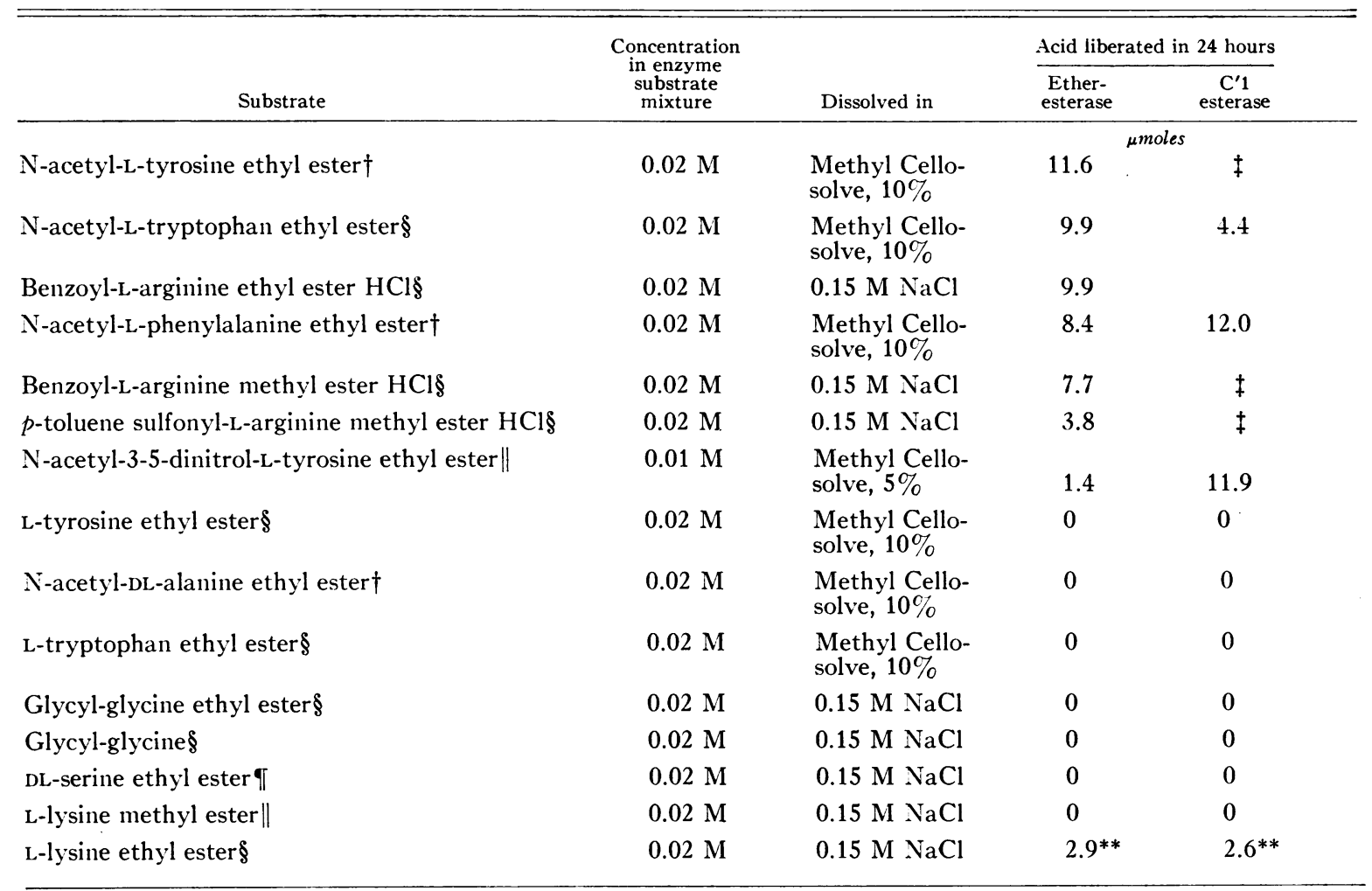

* Hydrolysis of these synthetic substrates by ether-esterase was determined by the method of Ratnoff and Lepow (19), with the exception of L-lysine ethyl ester. Acid liberated during incubation at $37^{\circ} \mathrm{C}$ for 24 hours was measured by means of a micro-formol titration. The results of experiments using $C^{\prime} 1$-esterase are those reported previously (19). The quantitative differences in effect of the two esterase preparations are unexplained.

$\dagger$ Department of Chemistry, Western Reserve University.

I Significant hydrolysis after 1 hour previously reported; not tested at 24 hours.

$\$$ Mann Research Laboratories, N. Y.

H. M. Chemical. Co., Santa Monica, Calif.

T Nutritional Biochemicals Corp., Cleveland, Ohio.

** The hydrolysis of this substrate was measured by a minor modification of the Hestrin method. $8.8 \mathrm{U}$ of etheresterase and $7.6 \mathrm{U}$ of $\mathrm{C}^{\prime} 1$-esterase were used in the incubation mixtures. The hydrolyses of other synthetic substrates by $C^{\prime} 1$-esterase are values which have been published by Ratnoff and Lepow (19). 
accounting for some of the discrepancies between original esterase concentration and the apparent uptake by the antigen-antibody aggregate (Table IV).

Antigen-antibody aggregates which had been incubated with either esterase inactivated $\mathrm{C}^{\prime} 4$ in proportion to the amount of esterase in the incubation mixture. The results were essentially identical whether $\mathrm{C}^{\prime} 1$-esterase or ether-esterase was employed (Figure 1).

6. Other substrates of ether-esterase. a) The hydrolysis of a variety of synthetic substrates was tested in an incubation mixture containing about $10 \mathrm{U}$ of ether-esterase. Products of hydrolysis were measured after an incubation period of 24 hours instead of the 15 minute period used in the standardized assay. It may be seen in Table $\mathrm{V}$ that large amounts of $\mathrm{N}$-acetyl-L-tyrosine ethyl ester were digested. Among those tested, the same substrates were digested by $\mathrm{C}^{\prime} 1$-esterase and ether-esterase.

b) Ether-esterase did not digest casein or denatured hemoglobin. A fibrin clot dissolved in about the same time whether it contained etheresterase or, instead, barbital-saline buffer. Unlike plasmin, this enzyme did not digest fibrin.

7. Other properties of ether-esterase. A pool of several ether-esterase preparations was found to contain 1 per cent or less of the Hageman factor activity, about 50 per cent of the Christmas factor activity, and about 25 per cent of the "proconvertin" activity of a pool of normal serum. It also contained a minimal amount of thrombin (clot formation in 55 minutes). It was rich in plasminogen, but contained no measurable plasmin or plasminogen-activator. No plasmin inhibitor was detected.

A preparation of ether-esterase was stable at $4^{\circ} \mathrm{C}$ for 1 week, and lost about half of its activity during a second week at this temperature. No activity was lost at $37^{\circ} \mathrm{C}$ over a period of 3 hours, but it was completely inactivated by heating to $56^{\circ} \mathrm{C}$ for 30 minutes.

The electrophoretic mobility of ether-esterase on paper was similar to that of an $\alpha$-globulin at $\mathrm{pH} 8.6$ and ionic strength 0.15 .

\section{DISCUSSION}

Extraction of serum with ether in the manner described resulted in the separation of a fraction rich in esterase activity. The experiments described suggest the identity of this esterase with an esterase derived from a preparation of the first component of complement. The esterase obtained by ether extraction of serum and that prepared from a partially purified preparation of the first component of complement both inactivated the fourth component of complement, hydrolyzed the same spectrum of synthetic amino acid esters, transferred to antigen-antibody aggregates in comparable fashion, and were inhibited by the same fraction of serum. In addition, fractions of serum lacking the first component of complement did not develop esterase activity following ether extraction. In the absence of more direct means of describing ether-esterase and $\mathrm{C}^{\prime} 1$-esterase, a comparison of the above properties offers the only means of identification at this time. The specific activity was usually two or three times that of a previously described preparation of $C^{\prime} 1$-esterase (2).

Some of the synthetic amino acid esters hydrolyzed by both $C^{\prime} 1$-esterase and ether-esterase have also been reported as satisfactory substrates for the esterase activity which may be eluted from antigen-antibody aggregates that have been treated with human complement. This activity has also been attributed to $C^{\prime} 1$-esterase $(7)$.

The preparation of ether-esterase contained plasminogen. However, fibrin was digested only when streptokinase was added. In the absence of streptokinase, ether-esterase did not digest casein, denatured hemoglobin or fibrin, suggesting that it contained no appreciable activity attributable to plasmin. Thus, this extraction had not activated plasminogen to plasmin.

Thrombin was also present in negligible amounts, but this enzyme has not been reported to hydrolyze $\mathrm{N}$-acetyl-L-tyrosine ethyl ester (28).

The mechanism by which ether extraction activates this esterase is unknown. Activity attributable to $\mathrm{C}^{\prime} 1$-esterase has been demonstrated in certain serum fractions treated with streptokinase or plasmin (6). Perhaps treatment of serum with ether could activate plasmin, and this enzyme in turn could activate the esterase. However, ether has been shown not to activate plasminogen to plasmin (38), an observation confirmed in the present paper. No activity resem- 
bling that of plasmin has been demonstrated in preparation of ether-esterase.

Perhaps a more likely mechanism relates the activation of ether-esterase to the disappearance of human serum inhibitor to C'1-esterase during ether extraction. For example, removal of the inhibitor might have allowed the esterase to evolve from a precursor, possibly by autocatalysis. Alternatively, removal of the inhibitor may have liberated preformed esterase. This suggestion, however, is not compatible with earlier studies demonstrating that $\mathrm{C}^{\prime} 1$-esterase evolves autocatalytically from an inactive precursor (6). The physical conditions under which activation occurred, namely, the process of thawing, prevented studies of the kinetics of the activation process. In addition, the destruction of the inhibitor by ether precluded studies of the effect of added inhibitor on the activation process.

Klein (39) has reported the formation of a stable complex of $\mathrm{C}^{\prime} 1$ and sensitized sheep red cells. He observed that treating guinea pig serum with large amounts of ether resulted in the destruction of $\mathrm{C}^{\prime} 4$ in this serum. This preparation lacking $\mathrm{C}^{\prime} 4$ was found to be anticomplementary after incubation at low temperature for 6 to 8 hours. It is possible that this anticomplementary effect was related to the evolution of esterase activity derived from $\mathrm{C}^{\prime} 1$ and identical to that described in the present paper. In addition, he noted that serum from which $\mathrm{C}^{\prime} 4$ had been removed by treatment with hydrazine inhibited the hemolytic activity of a complex of sensitized red cell and $C^{\prime} 1$. This effect was not found in serum from which $\mathrm{C}^{\prime} 4$ was removed with ether. These and other observations led him to conclude that serum itself interfered with the reaction between $\mathrm{C}^{\prime} 4$ and a complex of sensitized red cell and $\mathrm{C}^{\prime} 1$. This inhibitory effect was largely destroyed by ether, as was found to be true in the present studies.

Austen (40) has provided evidence that an esterase which is identical with $\mathrm{C}^{\prime} 1$-esterase may be found in serum treated with chloroform. He too was unable to demonstrate that this activity was due primarily or secondarily to the activation of plasmin. It is possible that the esterase he described is identical with the ether-esterase herein reported.
SUMMARY AND CONCLUSIONS

A method of extracting fresh serum with ether which activates a proesterase contained therein has been described. A large portion of the esterase formed ("ether-esterase") may be separated from an extracted fraction by centrifugation. This activity can not be identified with plasmin.

The properties of ether-esterase suggest its identity with an esterase derived from the first component of complement. It is capable of inactivating the fourth component of complement in a serum fraction lacking the first component. This action is prevented by a purified preparation of a human serum inhibitor of $\mathrm{C}^{\prime} 1$-esterase. Moreover, ether-esterase activity could not be extracted from serum lacking $C^{\prime} 1$.

The synthetic amino acid esters digested by ether-esterase are those which have been described as suitable substrates for C'1-esterase. $\mathrm{N}$-acetyl-L-tyrosine ethyl ester appears to be the most satisfactory of those substrates tested for both esterase preparations. The digestion of this substrate by ether-esterase is also prevented by suitable amounts of purified human serum inhibitor of $\mathrm{C}^{\prime} 1$-esterase.

Comparable amounts of $\mathrm{C}^{\prime} 1$-esterase and of ether-esterase may be transferred to a preformed antigen-antibody aggregate.

The mechanism of activation of ether-esterase appears to be mediated through the destruction of serum inhibitor of $\mathrm{C}^{\prime} 1$-esterase. It was not possible to demonstrate that plasmin played a role in this activation, or even that plasmin was activated by this extraction procedure.

\section{ACKNOWLEDGMENTS}

The author is particularly grateful to Dr. Irwin $\mathrm{H}$. Lepow for his assistance and suggestions in the course of this work and in preparing the manuscript, to Dr. Oscar D. Ratnoff for his help and encouragement, and to Dr. Irvine H. Page for his helpful criticisms of the manuscript.

I am indebted to Dr. Jack Pensky, Institute of $\mathrm{Pa}$ thology, Western Reserve University, for making preparations of purified human serum inhibitor of $C^{\prime} 1$-esterase available, and to $\mathrm{Mr}$. Earl Todd, also of the Institute of Pathology, who provided $\mathrm{C}^{\prime} 1$ and $\mathrm{C}^{\prime} 1$-esterase. Dr. James Ruegsegger, Lederle Laboratories, Pearl River, N.Y., generously provided the streptokinase used in these studies, and Merck Sharp and Dohme, West Point, $\mathrm{Pa}$., the commercial human plasmin. 


\section{REFERENCES}

1. Lepow, I. H., Wurz, L., Ratnoff, O. D., and Pillemer, L. Studies on the mechanism of inactivation of human complement by plasmin and by antigen-antibody aggregates. I. The requirement for a factor resembling $\mathrm{C}^{\prime} 1$ and the role of $\mathrm{Ca}^{++}$. J. Immunol. 1954, 73, 146.

2. Lepow, I. H., Ratnoff, O. D., Rosen, F. S., and Pillemer, L. Observations on a proesterase associated with partially purified first component of complement ( $\left.C^{\prime} 1\right)$. Proc. Soc. exp. Biol. (N. Y.) 1956, 92, 32.

3. Becker, E. L. Concerning the mechanism of complement action. II. The nature of the first component of guinea pig complement. J. Immunol. 1956, $77,469$.

4. Lepow, I. H., and Pillemer, L. Studies on the mechanism of inactivation of human complement by plasmin and by antigen-antibody aggregates. II. Demonstration of two distinct reaction stages in complement fixation. J. Immunol. 1955, 75, 63.

5. Pillemer, L., Ratnoff, O. D., Blum, L., and Lepow, I. H. The inactivation of complement and its components by plasmin. J. exp. Med. 1953, 97, 573.

6. Lepow, I. H., Ratnoff, O. D., and Levy, L. R. Studies on the activation of a proesterase associated with partially purified first component of human complement. J. exp. Med. 1958, 107, 451.

7. Lepow, I. H., Ratnoff, O. D., and Pillemer, L. Elution of an esterase from antigen-antibody aggregates treated with human complement. Proc. Soc. exp. Biol. (N. Y.) 1956, 92, 111.

8. Hinz, C. F., Picken, M. E., and Lepow, I. H. Studies on immune hemolysis. II. The Donath-Landsteiner reaction as a model system for studying the mechanism of action of complement and the role of $\mathrm{C}^{\prime} 1$ and C'1-esterase. J. exp. Med. 1961, 113, 193.

9. Lepow, I. H., and Ross, A. Studies on immune cellular injury. II. Functional role of C'1-esterase in immune cytotoxicity. J. exp. Med. 1960, 112, 1107.

10. Liefmann, J. Komplementwirkung und Katalyse. Z. Immun.-Forsch. 1913, 16, 503.

11. Becker, E. L. Concerning the mechanism of complement action. I. Inhibition of complement activity by diisopropyl fluorophosphate. J. Immunol. 1956, 77, 462.

12. Pillemer, L., and Ecker, E. E. The terminology of the components of complement. Science 1941, 94, 437.

13. Levy, L. R., and Lepow, I. H. Assay and properties of serum inhibitor of $\mathrm{C}^{\prime} 1$-esterase. Proc. Soc. exp. Biol. (N. Y.) 1959, 101, 608.

14. Bier, O. G., Leyton, G., Mayer, M. M., and Heidelberger, M. A comparison of human and guinea pig complements and their component fractions. J. exp. Med. 1945, 81, 449.
15. Kabat, E. A., and Mayer, M. M. Experimental Immunochemistry. Springfield, Ill., Charles C Thomas, 1948.

16. Baumgartner, W., Cole, R. B., and Ciminera, J. L. Assay procedure for quantitative determination of clot lysis activity. Vox Sang. (Basel) 1960, 5, 416.

17. Ratnoff, O. D. Studies on a proteolytic enzyme in human plasma. I. The probable identity of the enzymes activated by chloroform and by filtrates of cultures of beta hemolytic streptococci. J. exp. Med. 1948, 87, 199.

18. Christensen, L. R. Methods for measuring the activity of components of the streptococcal fibrinolytic system, and streptococcal desoxyribonuclease. J. clin. Invest. 1949, 28, 163.

19. Ratnoff, O. D., and Lepow, I. H. Some properties of an esterase derived from preparations of the first component of complement. J. exp. Med. 1957, $106,327$.

20. Pensky, J., and Levy, L. R. Purification and properties of C'1-esterase inhibitor of human serum. Fed. Proc. 1959, 18, 591.

21. Pensky, J. Further purification of a human serum inhibitor of C'1-esterase. Fed. Proc. 1960, 19, 76.

22. Donaldson, V. H. The effect of plasmin in vitro on clotting factors in plasma. J. Lab. clin. Med. 1960, $56,644$.

23. Owren, P. A., and Aas, K. The control of Dicumarol therapy and the quantitative determination of prothrombin and proconvertin. Scand. J. clin. Lab. Invest. 1951, 3, 201.

24. Tocantins, L. M., Ed. The Coagulation of Blood. New York, Grune and Stratton, 1955, p. 94.

25. Norman, P. S. Studies of the plasmin system. I. Measurement of human and animal plasminogen. Measurement of an activator in human serum. J. exp. Med. 1957, 106, 423.

26. Northrup, J. H., Kunitz, M., and Herriott, R. M. Crystalline Enzymes. New York, Columbia University Press, 1948, p. 307.

27. Peters, J. P., and Van Slyke, D. D. Quantitative Clinical Chemistry. Methods. Baltimore, Md., Williams and Wilkins, 1932, vol. II, p. 816.

28. Sherry, S., and Troll, W. The action of thrombin on synthetic substrates. J. biol. Chem. 1954, 208, 95.

29. Hestrin, S. The reaction of acetylcholine and other carboxylic acid derivatives with hydroxylamine, and its analytical application. J. biol. Chem. 1949, 180, 249.

30. Sherry, S. Personal communication.

31. Folin, O., and Ciocalteu, V. On tyrosine and tryptophane determinations in proteins. J. biol. Chem. 1927, 73, 627.

32. Ratnoff, O. D., and Colopy, J. A familial hemorrhagic trait associated with a deficiency of a clotpromoting fraction of plasma. J. clin. Invest. $1955,34,602$.

33. Quick, A. J. The determination of prothrombin by the method of Quick in Transactions of the First 
Conference on Blood Clotting and Allied Problems, T. E. Flynn, Ed. New York, The Josiah Macy, Jr. Foundation, 1948, p. 170.

34. MacFarlane, A. S. Behavior of lipoids in human serum. Nature (Lond.) 1942, 149, 439.

35. Jobling, J. W., and Petersen, W. The nature of serum antitrypsin. XIII. Studies on ferment action. J. exp. Med. 1914, 19, 459.

36. Alkjaersig, N., Fletcher, A. P., and Sherry, S. Epsilon-aminocaproic acid: An inhibitor of plasminogen activation. J. biol. Chem. 1959, 234, 832.

37. Lepow, I. H. Inhibition of human $C^{\prime} 1$-esterase by its partially purified human serum inhibitor. Fed. Proc. 1960, 19, 76.
38. Yamakawa, S. The autodigestion of normal serum through the action of certain chemical agents. J. exp. Med. 1918, 27, 689.

39. Klein, P. G. Studies on immune hemolysis: Preparation of a stable and highly reactive complex of sensitized erythrocytes and the first component of complement $\left(\mathrm{EAC}^{\prime} 1\right)$; inactivation of cell-fixed $\mathrm{C}^{\prime} 1$ by some complement reagents. J. exp. Med. 1960, 111, 77.

40. Austen, F. K. Differentiation of a chloroform-induced esterase of human serum from plasmin and its possible identity with the first component of complement (abstract). J. clin. Invest. 1959, 38, 984. 